JSCMT

Journal of Sustainable Construction

Materials and Technologies

J. Sustain. Construct. Mater. Technol. 2(2) (2017) 120-131
Journal of Sustainable

Construction Materials and Technologies

http://www.eds.yildiz.edu.tr/jscmt

\title{
Evaluation of Risk in Turkish Construction Sector
}

\author{
Bilal Çelik $^{1, \mathrm{a}}$, Mehmet Fatih Altan ${ }^{1, \mathrm{~b}, *}$ \\ Department of Civil Engineering, Faculty of Engineering, Istanbul Aydin University, Istanbul, Turkey \\ abilalcell@gmail.com, ${ }^{b}$ mehmetaltan@aydin.edu.tr
}

Received June 17, 2017; accepted August 4, 2017

\begin{abstract}
Construction projects, from feasibility and design abstract step is carried out, until a concrete step in the termination of operations contains a number of uncertainties and risks. day by day growing scale of our age and of various disciplines acquired a building complex with participatory projects require more professional methods of project risk management team and trained in this regard. Basically intuition, risk assessment and management in the construction industry, are based on judgment and experience in a logical manner. With risk assessment and the recognition was a major element of management applications for the building industry, industry response and especially related to the strategy used for risk assessment and management it is known very little.
\end{abstract}

Keywords: construction, construction projects, risk assessment, risk management

\section{Introduction}

In our era of rapid differentiation in the globalizing world gradually, not showing improvement, technological, economic and political have changed gradually due to the uncertainty. Risks of noting that the company will undertake an effective role in decision making system. It is worth noting that the uncertainty, businesses can determine the strategy for the future direction, it is necessary to understand the risk management mechanism in order to reach their goals.

A great number of risk factors hosting systematically evaluate and make the right decision and the appointment regularly strategies and objectives in the process of risks in the construction sector in due to the additional dynamic structure to the risks raised by the political and economic uncertainty poses a great importance for businesses that operate in this sector.

In order to have the project goals be able to see risks with the anticipated result of early and correctly, to analyze the effects and reduce all these risks and to take control, with the active project control mechanisms and methods

\footnotetext{
* Corresponding author.

E-mail address: bilalcell@gmail.com (B. Çelik)

https://doi.org/10.29187/jscmt.2018.16
} 
and planning will follow to take the measures necessary in this way; projects that are needed to prevent the success of risk management to reduce the possible negative consequences of force.

Control the level of risk in construction projects and to minimize, to get healthy measures against various risks, eliminating or reducing the effects of possible risks, such as preventing the reflection of the costs that are added to the project cost considerations that could eliminate a number of problems in the construction industry and are issues that could benefit the development.

\section{Construction Sector}

People address the needs of life which are built for centuries. This construction process is more complex as time progresses with advancing technology and increasing opportunities have come to a situation. In the first moments of the methods used in the project it has been an easy and satisfactory quality effects. However; modern technology tools maker of previous time as they replace the old ones, it should also have the ability and propensity to maintain their differentiation requirements. By increasing globalization, the planning of all types of projects and a large number of different expertise for the creation, capabilities and new industry products has occurred particularly in the last period. This gave rise to the use of time and resources of the companies under study in the construction sector (Kaya, 2009: 61). In the construction industry in general different from the other sectors, the investment cost of products is formed. Due to the increased number of construction investment, operating costs, cash informal walk through participation in both the construction tender, and may require a bank loan due to possible mismatches between production steps in the sales income or entitlement spending time with their earnings (INGEÇ, 2009: 1).

When a comparison carried out at the sectoral level in terms of the use of information mechanisms, seated in the construction sector, the manufacturing sector compared to those in fabrication that can be seen to be much more behind. The main reason, in a one-time often unpredictable environmental conditions and the structure of the manufacturing is done there is no time to step on a non-concurrent with previous projects in relation to dissimilar. The realization of production in many sectors without any request for the production of goods and services is concerned. Jobs, being frequently recurring nature; uninterrupted and continuous production jobs again and specialization process and the situation seems to become standard in the product. However, the realization of production without demand in the construction sector in question is not the case. The work done is not repetitious. Sectors such as demand characteristics shows changes in product characteristics.

This is because the realization of rationalization structures location based products is different becoming a standard of physical infrastructure and environmental interaction is a difficult event. "How much prefabrication as the titles we carry, lift, the difficulty of the installation process to rationalize the negative effects. In addition, domestic demand is also characteristic is unique to the construction industry. Structures earthquake, influenced by climatic conditions, such as is done in different regions with different details. However, in the sectors of production conducted in closed spaces in this case it is not in question. Products in different factories been performed revealed as the same product." (Çıdık, 2008)

Construction projects in the construction sector in developed nations, especially in the historic maintaining existing historic fabric and structure extensively using them is to sustain the current conditions and technologies. Renewed or restored work done is done, it is included for the new life by assigning different functions. These processes are very carefully study makes work and advanced technology required. Among these is the need a good bit administration and planning. Exactly at this point is very significant in terms of risk management, project management is one of the branches stemming from the requirement, especially in developed and used in a common format. It repeats in advanced state governments by forcing the limits given in support of advanced technologies that are being incorporated into a force in the racing world. It becomes intelligent buildings are performed in succession in specific areas gradually. However, their construction and even risk management decisions in the granting of construction is used a lot. (Şener, 2012: 31). 
Construction sector is from other sectors, which makes available a plurality of different attributes. The most important finding of the research done on this subject as follows: "cultural project culture in the construction sector, and culture in the manufacturing industry, the company is the culture." The construction sector is few of the other sectors are as follows. (Yenipazar, 2006, 84-85):

- Construction projects compared to other industries there are short and limited duration.

- This short time members of the project team with the impact of the process of the present time and 'what should be the best. They are focused on the idea.

- Customers are focused on finishing the project on time customers done; planning, programming, etc. comprehensive description of the objectives to be achieved

- Costs and scheduling spent significant effort to control the performance basis.

- Unlike the manufacturing sector must control at every stage of the project in the construction industry. So things move fast. Audit shows direction.

- Performance may appoint individuals showing how it can work even better.

- Time pressure affects administrative decisions, delays cannot be tolerated.

- Timely completion of the project, the project allows for the payment of compensation to the organization and prevent customers.

- Productivity, is providing project is determined by the organization to benefit from the project.

- The main contractor (the contractor his client's contract) is activated by subcontractors compared to some of the areas of specialization of jobs in the construction project.

- It is depending on the project size, up to 20 or more different types of contractor and employees may be working on a single site within a certain period of time. Therefore, a civil organization transient is defined as a multiorganization. $\square$

- If we look at in terms of a single contractor, contractor employees are deprived of the control environment. $\square$

- In order to have requirements of the job, depending on the project schedule, employees can be included in the team or can be removed. Therefore; workers may stabilize the team.

- Several time pressure resulting from the completion date of the project, can be a comprehensive study of organizational policies and procedures will prevent formal socialization opportunities.

- Construction industry has no concept of standard products. This sector shows a design feature to the product repeated. Housing that can be mass-produced, co-operative projects in the project will not differ environmental characteristics will change.

- Location of the product is fixed. Buildings are objects that cannot be moved.

- Demand is uncertain. An economic crisis has led to the postponement or even cancellation of projects. The lack of investor demand is uncertain or permanently prevent investment in this sector. Therefore it cannot be industrialization in the sector

- Unlike the manufacturing sector, especially where a product is concerned, which is designed in accordance with customer expectations in design, located artistic concerns.

- Because of being very long production time and the variables in the construction industry feedback is difficult.

- Project size can vary depending on factors such as the length of the project period cash flow rate.

- The construction sector varies customer definition. Customer entrepreneurial side that the funding of the buildings, the user, the general contractor or the recipient of the finished product can be assumed by one or more roles. In any case, the concept for the customer, the customer expectations and responsibilities to the customer for 
as long as the building and will be different. But in any case to determine customer expectations and to design the building and the process in this direction, also in the running time have been in constant contact with customers is necessary to take into account the ideas and requests. The building will be delivered to users during construction or after sales services are to the fore here.

- Bid is made for the different finished products from other sectors in the construction industry. Therefore, it is necessary to estimate the pre-production costs. However, there is no unique characteristics of each project, the results are hampering the use in another project. The long production time, the environmental conditions of production and the country's social, political and economic conditions affected by increasing uncertainty. Therefore, it is difficult to estimate the cost.

- Individual involved in the process for each project (owner, designer, contractor, subcontractor, users, etc.) which will be different. The project team, the process is situated individuals and organizations in place, the owner, design team, procurement team, production team consists of business teams and at the request of property owners involved in the project team management team.

- Construction sector is a labor intensive sector in worldwide, particularly migrant individuals trying to low money and the temporary employment industry in the form of a walking figure. Generally it consists of working as expected from men. "82\% of employees working in the construction industry is to be paid or salaried position as anyone else. A very important part of the workers in the construction industry, has been working in this sector due to widely existing subcontractors. This raises the issue of insecurity in together. As reported by the TSI, the labor statistics, this figure is $55 \%$ in the construction sector was $61 \%$ for all workers registered in the social security sector." (Smoke and Etiler, 2013: 31).

Table1. Construction Sector Employment Rates (Reference: TÜİK)

\begin{tabular}{|l|l|l|l|l|l|}
\hline Years & 2012 & 2013 & 2014 & 2014 (January- June) & 2015 (January- June) \\
\hline Employment ( Thousands) & 1.717 & 1.768 & 1.912 & 1.848 & 1.876 \\
\hline Employment Growth (Percent) & 2,2 & 2,9 & 8,1 & 7,6 & $-1,1$ \\
\hline $\begin{array}{l}\text { Construction Sector Employment } \\
\text { Share (Percent) }\end{array}$ & 7,2 & 7,2 & 7,4 & 7,2 & 6,9 \\
\hline
\end{tabular}

Statements in general as the year goes on as seen in the construction industry has experienced an increase in employment. The construction sector is among the sectors that most employment the year in which employment growth is most experienced in 2014.

\section{Construction Sector in Turkey}

Looking at the different sectors in Turkey is a very good place as their size and position of the construction industry. However, the importance of the construction sector is not only arise from manufacturing industries. The construction sector is a large number of one and a maximum contribution to providing job opportunities for individuals, even if this is not the national economy. Out-fold return on their product quality and economy are also one of the biggest reasons why the severity of what constitutes the construction sector (Şener, 2012: 29).

Construction business line, are located within a state's economy in all important sectors. The construction sector, caused by the build sector and poses important in terms of the size of employment. The construction sector, which formed the sub-sector and employment because of the state's socio-economic development by providing benefits to the country's prosperity leads to higher dimensions. The construction sector in the development of many sectors also 
gives rise to development. Among these sectors; "Cement, iron and steel, ceramics, glass, natural stone, plastic building materials, paint and wood products sector is directly affected by developments in the construction sector. In the real estate sector and the banking sector in the development of the service sector has contributed to the development of the construction business."(Doğru, 2010: 46-47).

The construction sector as well as throughout the world, Turkey is an important economic activity which constitutes in terms of economy. largely be based on the domestic industry of the sector, the height of the employment rate, first is in relation to one of the busiest in other sectors, including industrial production, and due to the nature of the builder input exchange activities carried out abroad are considered as a sector which attracts the head of Turkey's economy. Therefore, the construction industry; benefit from the input and in terms of jobs created, the national earnings contribution of new business areas role in the creation, due to relations with other industries in transition to recovery from the recession has seen an important task (Khan, 2010: 7).

The concept of urbanization in Turkey has become more important with the concepts republic. Industry, investors ignored the agricultural and transportation sectors has led to investments in this direction. All the basis of a constructive activity due to the presence of Turkish foundations in the construction sector have occurred in this format. The first steps have been taken by the government and the intensity of the construction industry has been in infrastructure and public works. State support to private investors to share large comprehensive investment began to begin to unrealized. Investments worth noting that the use of technology grows, the needs and strategies for first production showed growth both in Turkey and abroad have been recruited in the construction field. In just it was not enough time advancing the progress of technology in the production branch, and there have been improvements in the management of the business. The need to manage risks to terminate born in obscurity and has formed many different ways. This method is still the majority of foreign origin is worth noting that there is still slowly started to be used in Turkey. In this sense, the most important with the introduction of improved methods of the concept of risk management as a whole has occurred (Şener, 2012: 30).

Timely development in the Republic period in the year of 1920 with significant first step in the construction branch, which in the future will be laid in Ankara, the capital. In Ankara, against all odds, it has entered into a development environment act according to the traditional building style despite transportation and equipment failure. Equipment used wood, adobe, were rough chipped stone like primitive equipment, they could not even provide enough. Republic with the purpose of rapid and planned development industry in Turkey, the importance given to investment in agriculture and transport branch, has laid the foundation of the Turkish construction sector. The first construction activities at this time, is seen in the construction of road transport. But the lack of trained technical workers, a foreign company time work has led to operate in specialist and consultant. (Hozan, 2006: 12).

Table 2 shows in 2005, the growth rate of gross domestic product in 2014. In a certain order among the industry's growth rate does not appear as shown in the table. Very serious figures in the construction industry gross product growth are outstanding. This is how the construction sector in Turkey reveals that it is important.

Turkey is a country which until this time of socio-economic renewal process, the proclamation of the republic in 1923. The population in the year 2020 to reach around 83 million between expectations. Rising population, urbanization shows high speed parallel. Proportion of urban population in 2007 has increased up to about $70 \%$. "Urban housing and infrastructure needs resulting from the growth comes directly means increased demand for the construction sector activities. In 2011, according to the first 9 months of data investment in the construction sector, public investment, 36.8\%, 63.2\% is private sector investment. Dağılımının1999 course between the public and private sectors and between fixed capitals investments in 2011 can be traced from Figure 1. "(Eşkinat and Tepecik, 2012: 30). 
Table 2. Growth Rate of Gross Domestic Product / Fixed Price $£ / 1.000$

\begin{tabular}{|c|c|c|c|c|}
\hline Years & The Growth Sector (\%) & Sector Shares (\%) & Construction Sector & General Economy \\
\hline 2005 & 9,3 & 5,8 & 5.250 .284 & 83.485 .590 \\
\hline 2006 & 18,5 & 6,4 & 6.220 .955 & 90.499 .730 \\
\hline 2007 & 5,7 & 6,5 & 6.573 .647 & 96.738 .320 \\
\hline 2008 & $-8,1$ & 5,9 & 6.040 .811 & 101.254 .625 \\
\hline 2009 & $-16,3$ & 5,2 & 5.067 .195 & 101.921 .729 \\
\hline 2010 & 18,3 & 5,7 & 5.996 .258 & 97.003 .114 \\
\hline 2011 & 0,6 & 5,8 & 6.688 .256 & 105.885 .643 \\
\hline 2012 & 7,1 & 5,7 & 6.726 .223 & 115.174 .724 \\
\hline 2013 & 7,0 & 6,0 & 7.198 .092 & 122.476 .094 \\
\hline $\begin{array}{l}2014 \text { nine } \\
\text { mouth }\end{array}$ & 2,9 & 5,8 & 5.480 .595 & 93.733 .151 \\
\hline
\end{tabular}

(References: TÜIK)

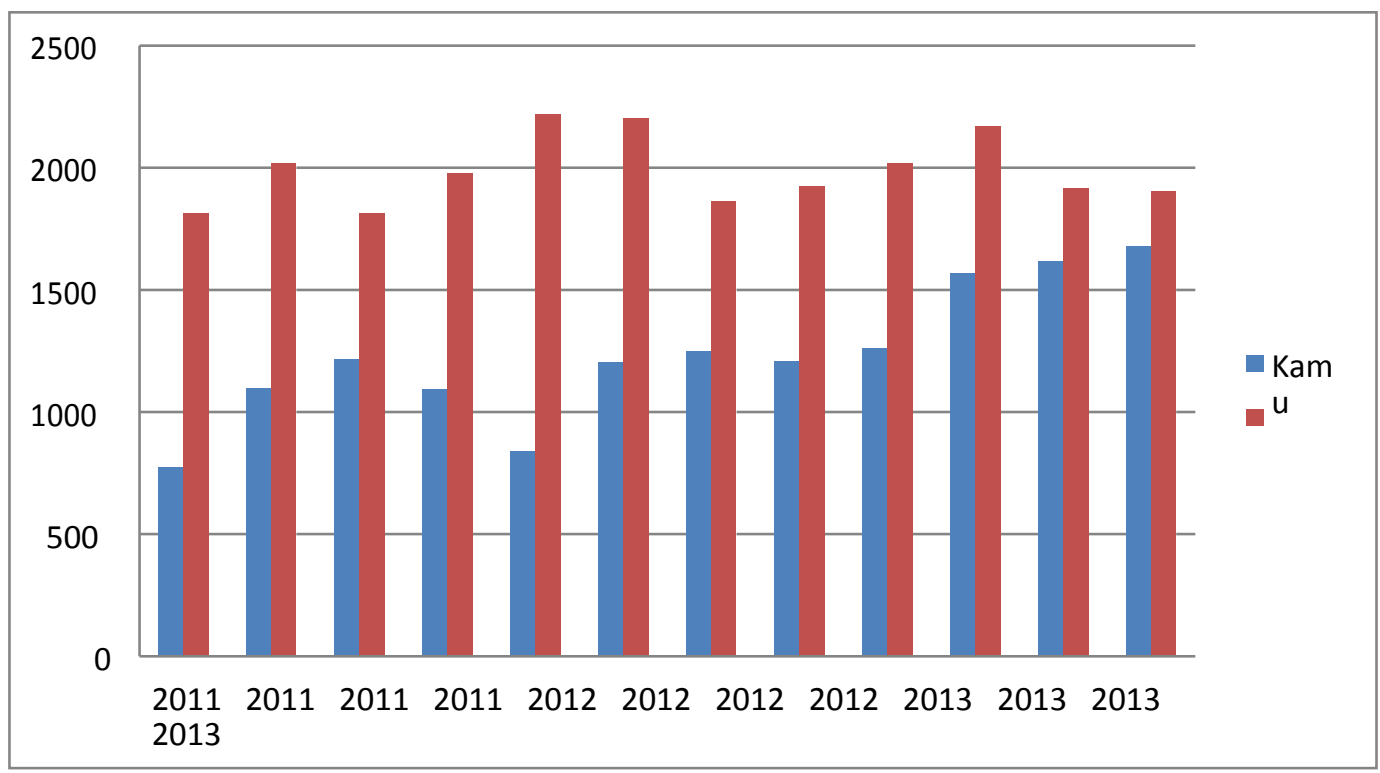

Fig. 1. Construction Sector Fixed Capital Investments (by year, \%) (Reference: TÜIK) 
Figure 1 shows the fixed capital investment in the construction sector in Turkey. Private investment in 2012 reached its peak. However, it was observed a decline in public investment in the same year. Public investment is seen that in the 4th quarter. However, in general terms the investment has not been playing much of a question most of 2013.

Trained technical staff has spent years in the 1970s to the industrial sector's activities specific to the history and the private sector. Investment worth is noting that the result of the spread of factory-built building has led to the development of prefabrication construction technology mechanism (İlhan, 2008).

Turkey, along with the industrialization occurring socio-economic differentiation, migration to the cities and the urbanization approach is to make a rapid and reached a level of housing construction in the construction sector are of fundamental importance. But a planned manufacturing transition facility found without result to be met in an uncontrolled manner the need occurred, despite the construction of unplanned and poor quality housing in the city issue. For negative image becomes a common, this time in Turkey's economy of housing construction, it is also true that a large contribution towards employment and investment. (Akalın et al., 1983).

The oil crisis emerged in the years 1973-74 in Turkey negatively affect all sectors. Due to the influential economic crisis and inflation from rising costs in the construction sector have given rise to the demand reduction sector. To leave the country corresponds to the time of the Turkish construction sector "The oil crisis of 1973-1974 and 1979-1980 period, which began after the second oil crisis, has led to increased investment in all sectors and development activities in the oil-producing Middle East and North African countries.

There are new markets, including infrastructure and especially housing, has drawn advanced countries experienced in the works since 1947. First in the US and European companies to the market, followed by firms belonging to the Asia and Far East countries. Turkish construction firms are able to enter the competition after 1978, and despite the challenges they face, took a bigger share according to many developing countries." (İlhan, 2008).

1980 years for years shown a great development of the construction sector in Turkey. This positive momentum has begun to stop in 1989. These factors have contributed to the development, the rate cut at the end of the period of investment in infrastructure 1980s years and liberalization policies cause operating in Turkey has been the upgrading of both investment and financing costs increased interest. The year of 1990 public deficit and public investment in the sector austerity measures from the 2000 year was affected negatively. This has changed the direction of progress in 2002 in the negative direction. Starting in 2004, demand for housing boom, have seen the extreme in 2006, it has been included in the standstill period since the second quarter of 2006 (Eşkinat and Tepecik, 2012).

When viewed from abroad to the Turkish contracting activity, it is observed that almost ten years of time are present in the break point occurred. 1970 paused domestic marketing of the year, the world oil crisis, the Cyprus Peace Operation and after country, industry, and businesses must be able to be pushed up under the difficult conditions. Problems in the Libyan market in the year 1980 occurred when the domestic critical infrastructure, housing, accommodation facilities was realized investments were directed to the domestic market but overseas market completely empty. As result of the termination of the Soviet Union, the Central Asian states, especially Russia, Azerbaijan, has witnessed another break causing the importance of Kazakhstan and Turkmenistan in 1990 In the 2000s, Turkish contractors the knowledge and experience gained in both domestic and overseas markets in various regions of the world and have been for years judged under different conditions. (Özorhon, 2012).

When we are observing at this table, how undeniably a market for Turkish contractors in Russia is clearly seen to be important. The value realized 1,373 projects with a share of $18 \%$ belongs to the Russian Federation in 2011. Russia, Libya, Turkmenistan, Kazakhstan, followed by Iraq and Saudi Arabia. 6,442 projects carried out in the last 40 years and there is a corresponding volume of 206 billion dollars. Turkish construction sector is active in certain areas where the historical ties of the main reasons it should, both said to be the country's geographical location and bilateral relations. Thus, the former Soviet Union countries and they stand out as the most important markets in the 
Middle East. North African countries such as Algeria Besides, European countries and Romania are also included in the rankings.

Table 3. Regional Distribution of International Projects (2012)

\begin{tabular}{|c|c|c|c|}
\hline Countries & Number of Projects & Total Project Cost ( US Dollars) & Percentage $(\%)$ \\
\hline Russia & 1.373 & 37.191 .894 .135 & 18 \\
\hline Libya & 525 & 26.300 .480 .672 & 12,7 \\
\hline Turkmenistan & 722 & 23.613 .414 .163 & 7,4 \\
\hline Kazakhistan & 372 & 14.850 .683 .052 & 5,8 \\
\hline Iraq & 631 & 11.946 .108 .521 & 4,7 \\
\hline Saudi Arabia & 157 & 9.761 .747 .015 & 3,7 \\
\hline Train & 66 & 7.669 .491 .738 & 3,6 \\
\hline UAE & 95 & 7.427 .771 .878 & 3 \\
\hline Romania & 166 & 6.113 .823 .739 & 2,9 \\
\hline Algeria & 174 & 5.914 .496 .807 & 26,9 \\
\hline Other & 2.161 & 55.618 .295 .478 & 100 \\
\hline Total & 6.442 & 206.408 .207 .198 & \\
\hline
\end{tabular}

(Reference: TMB, 2012)

\section{Risk assessment}

People provide a host of uncertainty in terms of future company. Occurrence may be characterized as risk probability of an undesirable thing. In handling to take place, albeit with low probability of such matters may lead to difficult problems in future periods. Therefore, it should be included in any decision on the future orientation of the account risk factors. (Berk, 1992).

The concept of risk can be easily mistaken as a concept was first detected. However, it is difficult to define this concept. In the literature does not change and it is not possible to find a consistent use. The origin of the word risk comes from the French. "Literally, the risk with the handling of daily use and the economy; a hand injury, damage, on the other hand can be seen as opportunities and become identical with lost earnings. In addition, risks, internal as internal to the "uncertainty" and "possibility" are mixed with concepts such as the concept of a lot of confusion to be used interchangeably further increase." (Kumar, 2010).

Risk assessment is the identification of hazards associated with OHS in an institution, how the decision might be harmed who, analyzing the risks, deciding on measures to be taken, the dangers to the implementation of these measures is a set of processes involving the replacement if necessary be continuously monitored and the risks and precautions. 
Before we get into the European Union in matters of detail (EU) will be useful to examine the issue in terms of perspective. This is because the majority of OHS regulations in Turkey are designed in parallel with EU directives. Step by step implementation in the EU are trying to be channeled to Turkey. The execution of work on the harmonization of the EU legislation, risk assessment and of great importance given system is based on this approach almost. In particular the Framework Directive No. 89/391, including kittens directives and risk assessment should be performed in other relevant directives (noise, vibration, like so much about hazardous chemicals) were continuously expressed. İmportance of the subject in recent years, especially in the EU has increased. European Agency for Safety and Health at Work has launched Risk Assessment Campaign in 2008. (Birgören and Yilmaz, 2015);

ISG is the first step in the management of risk assessment and the key role it has,

- The first step is not done correctly (or not done at all) probably cannot be taken in place measures,

- In many institutions, especially the right and sufficient risk assessment cannot be made in SMEs,

- The costs of ISG risk is very large,

- Risk awareness, perception and communication is very important in the prevention of occupational accidents and occupational diseases to occur, but it is at a very low level,

- Simple risk assessment, it should be made clear,

- The need to show how they apply to institutions

- Institutions and the need to be reminded that there is a legal requirement of a risk assessment, is highlighted.

- These assessments are carried out for the EU countries is extremely true for organizations in Turkey. Therefore, the General Directorate of Occupational Health and Safety, the risk assessment done, correct and complete in all institutions and in particular is making efforts to disseminate SME business in nature. Risk assessment seeks to answer the following question (Birgören and Y1lmaz, 2015):

- What could go wrong?

- What is the probability that?

- No matter what kind of consequences?

- What are the risks?

- Is this acceptable level of risk?

- How Risks reduced or eliminated?

The risk assessment process consists of different countries and institutions to step in at number five or more applications, but the contents are very similar to each other. Here parallel 5 -step with the European Agency for Safety and Health at Work approach offers an approach (Birgören and Y1lmaz, 2015)

1. Data collection, identification of endangered and risk

2. Analysis of risk

3. Agreed control measures

4. Transition to motion

5. Monitoring and reviewing goals.

\section{Risk Assessment in Construction Sector}

Investing in long-term projects such as the construction of buildings, for the construction industry in terms of the project, the project may be of indefinite duration and cost factors affecting the business of supply risk is expressed as a reason. No matter how the size of the project, all construction works are housed risk and uncertainty. One of the most important cause of the risk although the size of the project, other elements that incorporate the risk, complexity, speed of construction, the location of the project are estimated the total cost and uncertainty. A large number of project experience has revealed that undervalued these risks.

The first time a significant increase compared to determine the impact of the program on all projects in the project cost and time can become very dangerous. First detection and predictive way time and costs for these types 
of negative events affecting the realization often occurs and can be effective throughout the project. To walk as works planned to go to bad weather conditions, not given timely progress payments, planned changes in equipment, which entered the market wages are affected in a very simple way to cases such as that in a different way. This influences the duration of the work they perform, the cost and the quality can be reflected in a simple way. This early work of the reasons the project is planned to finish in time and cost deviations can occur in a simple way. These deviations contractor to avoid bankruptcy as it aims to reach earnings of construction companies may even result.

Target cannot predict these deviations have occurred in some cases even an experienced project manager. This situation occurs generally known, but for reasons not specified exactly. Because there are no construction projects that mate with each other, to predict their likelihood and impact is very difficult to precisely. This situation makes the detection of a significant source of risk for each project. Common features of construction risks are as follows (Kaya, 2010).

- Risks can be reduced to the minimum level checked; but they are never totally indestructible.

- Risks transferred to another person or party.

- The risks are relative, it varies depending on which side of view.

- Risks are abstract concepts, but can be controlled concretized in construction contracts.

In general, the risk of a Turkish construction company, it is seen that the state lost money in the form of understanding. The importance of planning and scheduling is adopted and which has no problem when performing properly widely blood will not occur. Risk management, the relevant planning authority as a factor not perceived as a problem. The biggest risk is that attention is given to unplanned work and no real necessity of the plans (Karachi, 2000).

Figs are relevant to this issue (2003) have gained in the study of the results is as Follows:

- Planning techniques widely used abroad, our country contractor with more than 5 years' experience in the construction sector are implemented by the construction company. However, businesses that processes are working to make their own planning departments without consulting support has come to the fore.

- Contractor construction companies, in the planning stages; time, cost and resource costs, the most important criteria in the more important shows.

- Project time invested in the construction industry, a calculation has been ignored or considered part of the risk factors that are determined on the basis of. In practice usually determine time based on the results of the past and preferred method of comparison with similar work.

- Our country project investment costs in the construction industry is generally determined by the Ministry of Public Works and Settlement unit price and foreign currency indexed analysis.

- Against risk approach to prevention in the construction sector, which have characteristics in common, as are applied to the additional cost and time analysis.

- The most important risk class in the risks affecting the implementation of projects in the construction sector, considered as the financial and economic risks, are considered within the scope of the risks posed by natural disasters are at least as important $5 \mathrm{~s}$ according to the assessment scale.

- Construction projects completed in the past, and the increased costs as a result of the planned completion later time frequently observed, emerging issues related to the implementation of the project results are comparable in quality cannot be ignored.

- In our country and in other countries, the transfer of risk on the contractor, is putting a common strategy against the risk of the employer.

- Turkey such as high inflation, the investment in an environment where frequently experienced economic crisis, according to the Planning Ministry of Public Works and Settlement unit price does not fully reflect reality.

Although many risk factors include the construction sector, our country risks being considered as unconscious and set time and cost limits are exceeded. As a result, disputes arise between the parties. While the more realistic 
approach of construction companies, cost and quality issues and determine their stand on the effects of risk factors in the control must take the necessary measures to end monitor and start the project. In our country, the widely used risk management; Identification of the risks of the construction sector, regulation and risk management between the parties of the people according to the risk of contracts and the use case will be able to be informed about the benefits (Ugur, 2006).

\section{Conclusion}

Construction projects, a whole generation into the complex structure of various labor groups, which vary at each step and any projects that contain elements that cannot be estimated due to host of high risk. Construction risk is the time of the construction project, cost and quality are the factors threatening. Risk assessment should not only be subject to a form of negative factors affecting the project objectives. In terms of business if it is correctly stated and well managed is also said to be an opportunity.

Studying to be a commercial enterprise is no risk endeavor with no return. Risks currently owned resources, is an integral part of the process is expected to be committed in the future. In fact, economic development, can be expressed as the ability to take more risks.

Project risk management is a fact that the balance between the potential benefits versus the risks associated in the project identified and targeted the balance of the earnings deterioration as to outweigh the execution of correct technique, a position that drives the economy in the developing states in terms of the construction sector, which is equipped with many of the attributes that can be an advantage.

In the construction sector; the project's size, complexity of, based on the environment in which to use strategy and realization, reproachfully in the evaluation of minimizing the conflicts that may arise between economic losses and parties of risks that different rates in each project is possible. The early steps in a risk management mechanism constructed and renovated projects during the entire project, especially those at high risk project is a project management method that can affect the success of the project as positive.

\section{References}

Birgören, B.,\& Yılmaz, F. (2015). İş Sağlığı Ve Güvenliğinde Standartlar ve Mevzuat ve Çerçevesinde Etkin Risk Yönetimi ve Değerlendirmesi. International Journal Of Engineering, 7(2), 1.

Çıdık, M. S. (2015). Türk İnşaat Sektöründeki Bilgi Yönetimi Uygulamalarında Yaşanan Problemler Ve Çözüm Önerileri (Doctoral Dissertation, Fen Bilimleri Enstitüsü).

Duman, E.,\& Etiler, N. (2013). İnşaat Sektörü ve İşçi Sağlığı. Mesleki Sağlık ve Güvenlik Dergisi (Msg), 13(48).

Eşkinat, R.,\& Tepecik, F. (2012). İnşaat Sektörüne Küresel Bakış, Afyon Kocatepe Üniversitesi, İDergisi.

Hozan, M. C. (2006). İnşaat Sektörünün Ekonomideki Yeri Ve Önemi Yayınlanmamış Yüksek Lisans Tezi), Diyarbakır: Dicle Üniversitesi Sosyal Bilimler Enstitüsü.

İlhan, B. (2015). Türk İnşaat Sektörünün Girdi-Çıktı Analizi Ve İthalata Bağımlılığı (Doctoral Dissertation, Fen Bilimleri Enstitüsü).

İngeç, E. (2009). İnşaat Firmalarının Kredi Talepleri Ve Bankalar Tarafından Kredilendirilmesi Sistemlerinin Değerlendirilmesi Ve Kredi Tahsis Model Önerisi (Doctoral Dissertation, Fen Bilimleri Enstitüsü).

Karaca, S. (2010). 1994-2010 Yılları Arasında Yaşanan Ekonomik Krizlerin Türk İnşaat Sektörüne Etkilerinin İncelenmesi(Doctoral Dissertation, Fen Bilimleri Enstitüsü).

Kaya Özlem (2010). “Türk İnşaat Sektöründe Risk Analizi Ve Yönetiminin Araştırılması” Yıldız Teknik Üniversitesi Fen Bilimleri Enstitüsü, Yüksek Lisans Tezi, İstanbul. 
Kaya, S. (2009). nsaat Sektorunde Iletısım Ve Iletısım Stıllerı Uzerıne Bır Arastırma (Doctoral Dissertation, Fen Bilimleri Enstitüsü).

Ofluoğlu, G.,\& Doğru, T. (2011). Türkiye'de İnşaat İşkolu'ndaki İş Kazalarının Ekonomik Boyutları. Kamu-İş Dergisi, 11(4), 183-218.

Özorhon Beliz (2012). “Türkiye'de İnşaat Sektörü ve Dünyadaki Yeri” İstanbul Ticaret Odası Yayınları, Yayın No: 2012-31.

Şener, B. (2012). İnşaat Şirketlerinde Riskin Algılanması ve Risk Azaltıcı Tedbirler (Doctoral Dissertation).

Tezcan Aslı (2015). “Türk İnşaat Sektörünün İşgücü İhtiyaç Analizi” Gazi Üniversitesi Sosyal Bilimler Enstitüsü, Doktora Tezi, Ankara.

TMB (Türkiye Müteahhitler Birliği) (2012). Yurtdış1 Müteahhitlik Hizmetleri, http://www.tmb.org.tr/genel.php?ID=2

Uğur, L. O. (2006). İnşaat Sektöründe Riskler ve Risk Yönetimi. Türkiye Müteahhitler Birliği Yayını, Ankara. 